\title{
GEORG HEYM, DIECINUEVE VENTANAS A SU POESÍA
}

\author{
Pascual Riesco Chueca \\ (Universidad de Sevilla) \\ riescochueca@us.es
}

RESUMEN: Estas líneas proponen un recorrido por la producción poética de Georg Heym, figura iniciática del Expresionismo alemán. El objeto de la selección realizada es mostrar la diversidad de fuentes que nutren al autor, y que someten su obra a un delicado pulso entre herencia e innovación. La cuidada métrica resiste la presión de una temática rebosante de obsesión y presagio. Una cultura potente y suicida, la de la Alemania de anteguerras, desborda por boca del autor en una alocución donde creación y destrucción conviven en misterioso e íntimo connubio.

PAlabras Clave: Georg Heym, Expresionismo alemán, Paisaje, Métrica, Tradición.

\section{GEORG HEYM, NINETEEN WINDOWS TO HIS POETRY}

ABSTRACT: These lines propose a journey through the poetry of Georg Heym, an initiatory figure of German Expressionism. The selection aims to highlight the diversity of sources nourishing the author's production, a diversity poising his work on a complex equilibrium between heritage and innovation. Impeccable metric schemes resist the pressure of a repertoire brimming with obsession and omen. A powerful and suicidal subject, the German pre-war culture, overflows in a poetic discourse merging creation and destruction into a mysterious and intimate blend.

KEYWORDS: Georg Heym, German expressionism, Landscape, Metrics, Tradition.

Muerto en la flor de los años, cuando su inspiración subía como un meteoro de los que surcan gloriosamente su poesía, la figura de Heym (1887-1912) es el mágico exponente de una cultura rica y violenta: la de aquella Alemania refinadísima que resplandecía en todas las artes incluida la de la guerra. La crítica, no sin controversia, ha situado su obra en los albores del Expresionismo. El autor fue introducido en España por la influyente antología de Jenaro Talens, de 1971, que ha conocido reediciones ampliadas hasta incluir veinticinco poemas heymianos (Talens y Keil, 1997: 100-173). Acaba de aparecer una bella traducción del primer y único poemario publicado en vida por el autor, Der ewige Tag [1911] (Armas, 2018).

El recorrido que aquí proponemos quiere mostrar las riquezas y paradojas de su evolución, espigando algunas conquistas creativas que, dentro y fuera del modo expresionista, le fue dado acopiar en su corta pero prodigiosa carrera literaria. La selección es instintiva, basada en el simple placer de lectura, y está ordenada cronológicamente: he renunciado a incluir poemas que ya figuran en ediciones impresas en español. Traduje la mayor parte de estos poemas hacia 1991, y desde entonces he ido arreglando y ajustando las versiones, a medida que encontraba ediciones en otras lenguas y comentarios críticos. ${ }^{1}$ Mis iniciales predilecciones por la cacharrería

${ }^{1}$ Los originales en alemán se han tomado de la edición de Schneider (Heym, 1960-1964). Los corchetes [ ] encierran pasajes que Heym se planteó suprimir; los paréntesis angulares $<>$ envuelven un 
expresionista de Heym han ido palideciendo ante nuevos hallazgos lectores: su vibrante pluma pictórica, la pureza de su conciencia del paisaje, y las casi furtivas trazas de un impensado placer de vivir, engastadas como perlas en la noche de sus versos.

La maquinaria de un poeta grande como este es radicalmente misteriosa. Sobre la silueta de Heym se acumulan las contradicciones: el revolucionario encorsetado por la métrica, el jocundo estudiantón pero solitario sensitivo, el cronista de apocalipsis y disfrutador de ponientes, el expeditivo galán y el pudibundo poeta. Nacido y criado en las profundidades de Prusia, donde lo germánico vira a lo eslavo, se hincha los pulmones con lejanías griegas y exóticas, de hechuras librescas. La violencia de sus metáforas - como antídoto al hastío propone cataclismos- remite a Nietzsche y a los aires pre-bélicos. De sus tutores franceses, Rimbaud y Baudelaire, injerta en la poesía alemana novedosos recursos y encuadres, omitiendo, sin embargo, con férrea vigilancia cualquier deslizamiento hacia las franquezas eróticas. Su tono visionario coexiste con su radical llaneza, ajena a todo amaneramiento hermetista. Una rebeldía dionisiaca se conjuga con la firme carrera de jurista, la impregnación militar. Su tenaz afán comunicativo lo lleva a moldear sus poemas en tono narrativo; hasta los más breves parecen fragmentos de un relato perdido. Y preside su extensa obra poética una casi sobrenatural soltura: los acentos y las rimas se ordenan claros, como robados al vuelo de un viento de pentámetros. Aquí se anuda la contradicción suprema: tinieblas y espantos en un universo en desguace, sí, pero infatigable afán de decir ¿a quién?; tétricos ámbitos perforados por el espanto, pero mirada diligente que reúne estampas exaltadas por la belleza del mundo.

\section{EN EL OTOÑO ${ }^{2}$}

Nos gusta lo perecedero y cansado, el fulgor final del occidente, tan pesaroso y bello como si para siempre con él partiese también la juventud nuestra.

Y muchas hojas, desde las ramas deslizando sobre tu pelo, caen con temblor tenue, como si quisieran labrarse en oro la mortaja y morir en la belleza. ${ }^{3}$

Se combina en este poema temprano el regusto decadentista, espolvoreado sobre la vieja ecuación entre otoño y fin de la juventud, ${ }^{4}$ con un tímido madrigal en la segunda estrofa. El yo poético se escamotea, estrategia habitual en Heym. En la primera parte, se esconde en un nosotros que tanto puede aludir al alma plural de los sensitivos como englobar a una pareja, bajo una predilección compartida. En la segunda, hace irrupción

texto oscuro. No me son conocidas traducciones previas al español, en texto impreso, de los poemas seleccionados (sí en otras lenguas, en fuentes que se especifican en la bibliografía). Las traducciones al español, tanto en texto como en notas, son del autor.

${ }^{2}$ IM HERBST // Wir lieben das Vergehende und Müde, / Den letzten Glanz im Abendlande, / Den Traurigen und Schönen, / Als verschiede / Mit ihm auch unsre Jugend ewig. // Und manche Blätter von den Zweigen gleiten / Dir auf das Haar, noch zitternd leise, / Als wollten sie in Golde sich bereiten / Ein Grabtuch und in Schönheit sterben. [Traducción al portugués en Scheidl, 1985: 101].

${ }^{3}$ Heym, 1964: 622; agosto de 1906.

${ }^{4}$ Nada trágico se adivina en este decadentismo que celebra lo que de iluminador y esteticista encierra el declive (Korte, 1982: 31). Se añade la conciencia de pertenecer a una generación tardía, un «fulgor final del occidente» (Scheidl, 1985: 102). 
una segunda persona (Dir), que es acariciada por las hojas del otoño. Hojas que son trasunto del poeta y, plurales como el sujeto de la primera estrofa, se toman libertades en su nombre. 5

La medida de los versos, cambiante, de pies inciertos, la ausencia de rima en la primera parte, sugieren una musitación indecisa, de acordes amorfos. Ello contrasta con la mayor resolución de la segunda estrofa, compactada por la rima en los versos impares, que sugiere la audacia de un atrevimiento amoroso.

\section{POLONIA ${ }^{6}$}

Polonia, tierra hermosa

donde reside el luto

y las mujeres lloran

cuando la blanca luna

sobre los lagos luce.

Cuando la catedral antigua,

donde duermen los reyes

desde luengos siglos,

al sol de la tarde llamea,

suena el crujido en las criptas

de sus tahalíes viejos.

Mas no responde voz alguna

y el ruido de armas se apaga.

Pero de los bosques sombríos, que cobijan la sagrada tierra, parten aún las águilas

en bandada, como en pos

de una tropa de jinetes raudos,

y el pastor en las breñas

allá en los altos de Lysa Gora

despierta y de nostalgia lleno

sigue a las altivas águilas en vuelo. ${ }^{7}$

Se trata de uno de los raros momentos en que Heym evoca con alguna precisión sus geografías de infancia. El poeta nace en Hirschberg, en español Monciervo de Silesia, ciudad que hoy es de Polonia con el nombre de Jelenia Góra, y, siguiendo los destinos del padre, vive en Gnesen (Gniezno) y Posen (Poznań). El itinerario, que, como toda esta torturada frontera, ofrece frondosa toponimia multilingüe, concluye con el

${ }^{5}$ Idea que reaparece en el poema amoroso «Deine Wimpern, die langen» (Heym, 1964: 315; julio de 1911), «pero desde el álamo / que en el eterno azul se alza / ya baja una hoja parda / a posarse sobre tu nuca».

${ }^{6}$ Polen // Polen, schönes Land / Wo die Trauer wohnt, / Wo die Frauen weinen, / Wenn der weiße Mond / Auf Polens Seen glänzt. // Wenn der alte Dom, / Wo Polens Fürsten schlafen / Manch Jahrhundert schon, / In der Abendsonne brennt, / Rauschen sie in ihren Grüften / Mit den alten Wehrgehängen. / Doch es ruft sie keine Stimme / Und der Waffenklang verstummt. // Aber aus den dunklen Wäldern, / Die die heilge Erde decken, / Ziehen manchmal noch die Adler / Schwärmeweis, als wenn sie folgten / Einem Heer von schnellen Reitern / Und der Hirte in der Heide / Auf der Lysa Gora Höhen / Wachet auf und voller Sehnsucht / Folgt er lang den stolzen Adlern.

${ }^{7}$ Heym, 1964: 648; mayo-octubre de 1907. 
traslado de la familia a Berlín. El poema evoca la ciudad de Gnesen, ${ }^{8}$ ya desde la distancia berlinesa.

Los versos suenan con tonos populares y el encanto de las cantigas que ensalzan, con rauda puntada poética, rincones amados del mapa. Es un género que, con distintos acentos, florece en la magna operación inventarial del Des Knaben Wunderhorn, se vuelve perfección poética en Heine, y tiene ecos en Unamuno, Verdaguer, A. Machado y la poesía gallega tras el Rexurdimento. Alguna pincelada - «los bosques sombríos / que cobijan la sagrada tierra»- muestra el magisterio de Hölderlin. La evocación es de trazo rápido, ${ }^{9}$ como torrente que baja sin entretenerse desde las impresiones primeras. A las fórmulas descriptivas del comienzo, con sincopado irracionalismo de cuño popular, suceden dos pasajes contrastados: la historia como confinamiento, en la bajada a los interiores lóbregos de la catedral, donde duermen con sueño inquieto los viejos reyes; la historia como expansión, en los vuelos de un bando de águilas, duplicados por el tropel mítico de los jinetes. El mismo pulso entre compresión y expansión nutre unos «Apuntes», de inspiración cancioneril, en Antonio Machado (1989: 608): el paisaje abierto, batido por las alas de la lechuza ( $«$ Sobre el olivar / se vio la lechuza / volar y volar»), contrasta con las cóncavas profundidades de la catedral, las tinieblas punzadas por «el velón de aceite / de Santa María».

\section{MORITURI $^{10}$}

Cuando los suicidas merodean buscando el fin, no se apartan de las calles y caminos trafagosos, para no tener lejos las rodantes olas de la vida cuando, dispuestos a la muerte, ya se tumben.

Así, se lanzan desde puentes a los ríos, desde enjambres humanos al país de los muertos. En el tumulto de la ciudad oirás sus disparos, más que allá donde amaga solitaria la calma.

Porque aunque el pesar vuelva de hielo el alma y aunque quede entre las tinieblas yerta, aun a las puertas de la muerte espera en viaje de vuelta hacia la vida ser raptada.

Por eso saben esquivar los sombríos bosques, donde las lágrimas solo piedras al caer encuentran, y donde las penas del corazón, que nadie escucha, son devueltas por el eco en forma de carcajadas. ${ }^{11}$

\footnotetext{
${ }^{8}$ Schünemann (1986: 20) recuerda que en Gnesen se coronaban los reyes polacos.

${ }^{9}$ Rapidez reforzada por el uso de versos cortos y ritmo trocaico.

${ }^{10}$ MORITURI // Selbstmörder gehen, wenn sie sterben wollen, / Nicht weit von Straßen ab und vollen Wegen, / Daß nicht zu fern des Lebens Wogen rollen, / Wenn sie zum Tod bereit sich niederlegen. // Sie springen wohl von Brücken in die Flüsse, / Aus Menschenschwarme in das Land der Toten. / In Stadtlärm hörst du öfter ihre Schüsse, / Als wo dir Einsamkeit und Stille drohten. // Denn ist im Grame auch der Geist erfroren, / Und starr geworden in den Finsternissen, / Er wünschet dennoch an des Todes Toren, / Daß er zurück ins Leben werd gerissen. // So wissen sie den dunklen Wald zu meiden, / Wo ihre Tränen nur auf Steine fallen, / Und wo der Seele ungehörte Leiden / Im Echo als Gelächter widerhallen. [Traducción al inglés en Hasler, 2004: 12].

${ }^{11}$ Heym, 1964: 668; noviembre de 1908.
} 
El poema explora pulsiones suicidas, que Heym incuba a su paso por hoscas instituciones educativas. Es materia recurrente en el autor, que muestra una personal evolución en el tratamiento del tema. ${ }^{12}$ Es significativa la búsqueda, aun en la antesala del suicidio, de un público solidario o simpatizante (Leipelt-Tsai, 2015: 104): la autodestrucción se vuelve vaga empresa colectiva, ante una naturaleza que no solo es indiferente, sino sarcástica. La ciudad es el marco irrenunciable: los suicidas no pueden ni quieren abandonar su tumulto, donde aletean espíritus afines (Rölleke, 1966: 159). La contradictoria tensión planteada para la condición suicida (Hinck, 2004: 16) —deseo de destrucción; apego al bullicioso mundo- es extensiva al alma poética, y en particular a Heym: la misma sensibilidad extrema que lacera la mirada con signos tenebrosos y avisos de acabamiento, alimenta una intensa dependencia de las bellezas del mundo, los gestos de afecto y admiración en los coetáneos. Común a todos los poemas suicidiarios de Heym es el tratamiento plural del gesto: los suicidas componen un grupo, una legión confabulada.

\section{TORMENTA DEL OESTE ${ }^{13}$}

Avanza la comitiva por la techumbre del cielo.

Los negros mantos se arrastran por los campos

y un vuelo de sombras cubre bosques tenebrosos.

Los ríos se frenan en plomiza penumbra.

Guerreros de blanca barba, corvos sobre corceles, en pos del adalid que negramente blande la espada, $\mathrm{y}$, a saltos gigantes, rebasa ciudades

bajo amarilla humareda aplastadas. ${ }^{14}$

La personificación de la tormenta como guerrero es recurso antiguo, presente en numerosos autores; el propio Heym lo anticipaba en poemas de 1905 y 1909, «Un séquito nuboso por la orla sombría del cielo, / como rojos jinetes, que cabalgan caballos negros»; «Las nubes, grises, vuelan en grandes tropas, / resuena el clamor de la batalla sobre los sonoros vientos». ${ }^{15}$ El tratamiento bélico se ve favorecido por la polisemia de Sturm «tormenta; asalto». Dos cuartetos organizan el material, con perfecta oposición entre la techumbre del cielo del primer verso y el suelo aplastado bajo la humareda del último, entre la violenta dinámica de la tormenta y el miedo paralizante que frena por igual a ríos y ciudades. El poema da rienda suelta a una imaginación juvenil, transitada por jinetes apocalípticos (Scheidl, 1985: 105), con una escenografía que anticipa la contemporánea estética gótica y el cómic. Es significativo el uso del color: el negro de los mantos se radicaliza al trasponerse a un negro adverbial que describe cómo el adalid

${ }^{12}$ En 1906 Heym estaba en el severo Gymnasium de Neuruppin. Korte (1982: 32-22) cita poemas afines: (a) «Einem toten Freunde» (Heym, 1964: 607; 1905), (b) «Die Menschen stehen vorwärts in den Straßen» (Heym, 1964: 440; 1911), (c) «Die Selbstmörder» (Heym, 1964: 472; 1911). En 1905 hay decadentismo y culto a la belleza; en «Morituri» ya emergen innovaciones propias del lenguaje de Heym, que se desarrollan en los dos primeros poemas, (b-c).

13 DeR Weststurm // Am Himmelsdache zieht sich das Gereit. / Die schwarzen Mäntel schleppen durch die Felder, / Und Schatten fliegen über dunkle Wälder. / Die Flüsse stehn in blei'rner Dunkelheit. // Weißbärtge Krieger, auf das Roß gebückt / Dem Feldherrn nach, der schwarz den Degen schwingt, / Und riesgen Satzes über Städte springt, / Die in den Grund der gelbe Rauchqualm drückt. [Traducción al portugués en Scheidl, 1985: 104, 334; al francés en Iehl, 2012: 42].

${ }^{14}$ Heym, 1964: 64; abril de 1910.

15 «Ein Wolkenzug am dunkeln Himmelsrand, / Wie rote Reiter, die auf Rappen reiten» (Heym, 1964: 606). «Die grauen Wolken fliehn in großen Heeren, / Es hallt der Schlachtruf in den lauten Winden» (Heym, 1964: 672). 
blande su espada; sobre la oscuridad plomiza, fulge la blanca barba de los guerreros; las ciudades se agachan bajo la amarilla humareda de su aire venenoso.

\section{DEL FONDO DEL BARRANCO ${ }^{16}$}

Del fondo del barranco sube un muro de retamas, un mar dorado, movido por ligero viento, hasta lo alto de la loma, donde el ancho filo sostiene el desmedido azul del cielo. ${ }^{17}$

Con sencillez y belleza se registra aquí una impresión de paisaje. El «muro de retamas» no es un seto, sino un espeso retamar en flor, ladera arriba. La delicada arquitectura de las plantas y sus flores se resuelve en un exacto y dilatado filo. Magistralmente, compete a esta abstracta línea cargar con el peso inabarcable del cielo. Heym se sirve de sus bien engrasados endecasílabos, pentámetros yámbicos con rima $\mathrm{ABAB}$, sugiriendo una totalidad precaria pero sólidamente ensimismada.

\section{OH EXTENSA, EXTENSA TARDE ${ }^{18}$}

Oh extensa, extensa tarde. Ya se apagan las largas lomas en las brasas del horizonte, ricas de sol como paisaje de claros sueños. Oh tarde extensa, en la que los trigales mudan la luz del día en desparramado oro. A lo alto cantan, minúsculas, las golondrinas.

Por todo el campo relumbran sus correrías, en la maraña de juncos y en las claras bahías, donde se alzan altos mástiles. Pero en los barrancos, detrás de las colinas, está ya la noche anidando. ${ }^{19}$

De nuevo se manifiesta la atenta mirada al paisaje, de delicada traza impresionista. En este suave ocaso, los colores y luces se dilatan y se vuelven aéreos, enlazando el aquí con la lejanía. Contribuyen a extender y coser el lienzo las diminutas golondrinas en su incesante vuelo que llega a todas partes. Es de destacar el paralelismo entre dos bosques, uno artificial, de mástiles de barco, otro natural, de cañizos. En ambos se sugiere un movimiento ascendente, que se opone a la profundidad de los barrancos, donde ya anida la noche. El paisaje es expuesto con rica conciencia espacial, a través de movimientos de mirada horizontales, el zigzag totalizante de las golondrinas y el eje de cielo a abismo, por el que asciende silenciosa la noche en ciernes.

\footnotetext{
${ }^{16}$ VOM GRUND DER SCHLUCHT... // Vom Grund der Schlucht steigt auf des Ginsters Wand, / Ein goldnes Meer, von leichtem Wind bewegt, / Zum Kamm der Hügel, wo der weite Rand / Das ungeheure Blau des Himmels trägt. [Traducción al portugués en Scheidl, 1985: 328; al francés en Iehl, 2012: 47].

${ }^{17}$ Heym, 1964: 74; mayo de 1910.

${ }^{18}$ O WEITER, WEITER ABEND // O weiter, weiter Abend. Da verglühen / Die langen Hügel an dem Horizont, / Wie klarer Träume Landschaft bunt besonnt. / O weiter Abend, wo die Saaten sprühen // Des Tages Licht zurück in goldnem Schein. / Hoch oben singen Schwalben, winzig klein. // Auf allen Feldern glitzert ihre Jagd, / Im Wald des Rohres und in hellen Buchten, / Wo hohe Masten stehn. Doch in den Schluchten / Der Hügel hinten nistet schon die Nacht. [Traducción al portugués, parcial, en Scheidl, 1985: 104; al francés en Iehl, 2012: 67; al inglés en Hamburger y Middleton, 1966: 155 (Middleton)].

${ }^{19}$ Heym, 1964: 113; agosto de 1910.
} 
La métrica es cuidada, con rima consonante: el pareado central articula como bisagra de díptico la estrofa primera, habitada por la luz sin límites, y la segunda, donde se insinúa la sibilina subida de la sombra.

La hermosa versión que Christopher Middleton hizo del poema ( $\mathrm{O}$ boundless, boundless evening») sirvió de base para una composición musical, en la tradición de los Lieder, de Samuel Barber (Three Songs, Op. 45, 1972).

\section{EL LLANO $^{20}$}

Donde el calvo filo del calvo páramo se hunde en la indiferencia del lívido cielo, tres nubes van ardiendo, como, esgrimidos por manos funerales, tres hachones de entierro.

Se arrastra un coche por la desolación, lento, como lenta pesadilla de fiebre.

Y por la desierta extensión vaga el grito de gavilanes solos en el hosco espacio. ${ }^{21}$

Heym explora un paisaje metafísico, sembrado de barruntos funerales, mediante una mirada casi cinematográfica, con iconos amenazantes, grávidos de muda inminencia. ${ }^{22}$ Un fondo de prodigiosa indistinción, calvo, plano, indiferente, desdibuja su horizonte, confundiendo atributos del suelo y el cielo (Asser, 1973: 205). ${ }^{23}$ Sobre este lienzo, una mano traza líneas ominosas, como el indescifrable «Mane, Tecel, Fares» de la Biblia. Son signos lentos y deliberados, que avanzan simultáneos: el carruaje y su estela de polvo, el grito del gavilán o el movimiento velero de las nubes. Las imágenes de lo extenso son reforzadas mediante metáforas del movimiento (Steffen, 1965: 51). Lo infinito es habitado por lo incomprensible.

${ }^{20}$ DIE FLÄCHE // Wo sich der kahlen Ebene kahler Rand / Verliert in blasser Himmel Einerlei, / Brennen drei Wolken wie in einer Hand, / Die vor sich trägt der Totenfackeln drei. // Ein Wagen schleppt sich durch die Wüstenei / Langsam, wie ein langsamer Fiebertraum. / Und durch die leere Weite zieht der Schrei / Einsamer Sperber in dem trüben Raum. [Traducción al portugués, parcial, en Scheidl, 1985: 336; al francés en Iehl, 2012: 104].

${ }^{21}$ Heym, 1964: 180; diciembre de 1910.

${ }^{22}$ La estrofa inicial esboza un paisaje similar, amorfo y dominado por tres nubes que arden, al del poema «Ein Traum» (Heym, 1964: 179), escrito hacia la misma fecha (Scheidl, 1985: 336).

${ }^{23}$ Se ha visto en este tratamiento de la llanura una premonición de futuros poemas esteparios de Bobrowski (Durand-Henriot, 2000: 377). 


\section{NOSTALGIA DE PARÍS ${ }^{24}$}

Cuando cruzando la tarde francesa, que tiene

la blancura de lises de su escudo de armas,

el día de sol, dulce como la miel,

cálido cede por el lejano cielo ámbar,

palpitan entonces las campanas de Montmartre para despedir la jornada y su esplendor dorado. Pero sobre París, tirabuzones de añeja beldad, fulgen rojas nubes como guirnaldas nupciales.

Medio marzo, medio otoño, con lastimero aroma: quien una vez abrevó los pulmones en el viento, mientras rojas relucían las torres de Notre-Dame, desfallece luego bajo el delirio de la nostalgia.

Tu cáliz de bullicio, ceñido de sombra y rosas, la sangre le altera con veneno de oscura noche, y fija la vista en Occidente, donde lo miman con recatado fervor los vientos de Francia.

París, engendradora de arte, madre de la grandeza que como corona victoriosa rodea tu frente y soberbia sepulta bajo un bosque de laurel tus despojadas sienes, de anciana grisura:

\footnotetext{
24 Sehnsucht NACH PARIS // Wenn durch den Abend Frankreichs, der der Weiße / Der Königslilien ihres Wappens gleicht, / Wie Honig süß, der Sonnentag, der heiße, / <In honiggelbe Himmel> ferne weicht, // Dann zittern von Montmartre viele Glocken, / Und grüßen ihn und seinen goldnen Glanz. / Doch auf Paris, der alten Schönen Locken, / Glühn rote Wolken wie ein Hochzeitskranz. // Halb März, halb Herbst, voll trauriger Essenzen, / Wer je den Wind in seine Lungen trank, / Wenn rot die Türme Notre Dames erglänzen, / Er ist nach dir vor wilder Sehnsucht krank. // Dein Taumelkelch, umwunden schwarz mit Rosen, / Nachtschattengift erschüttert ihm das Blut, / Und westwärts schaut er <immer>, wo ihn kosen / Die Winde Frankreichs mit verhaltner Glut. // Paris, Mutter der Kunst, und jeder Größe / Die wie der Sieg auf deiner Stirne schwebt / Und deiner altersgrauen Schläfe Blöße / In einen Wald von Lorbeer stolz begräbt, // Wo tief in deinem Schoß im Sarkophage / Vom Fittich seiner Adler überwacht, / Der Kaiser schläft, und leise Totenklage / Im Dome wandert durch die Mitternacht, // Wo wie ein Wald die alten Fahnen stehen, / Die durch Ägypten trug die Legion. / Sie rauschen manchmal noch, die Tücher wehen / Wie Küsse sanft <um> deinen toten Sohn. // Doch morgens brennt im Osten auf der Seine / Im Häusermeere wie im Sturm-Fanal / Im Mastenwald, im Meer der schwarzen Kähne / Die Sonne blutig, wie ein großer Gral // Vom roten Wein gefüllt bis an die Borde, / Vom Wein der Freiheit, der das Herz beschwört, / Und auf der weiten Place de la Concorde / Aus Dantons Mund der Städte Zorn empört. // O großer Tag, da rote Donner grollten / Auf deiner Stirn, und blutig, fett und feist, / Des Königs armes Haupt im Sande rollte, / - Großes Paris, das altert und verwaist, // Noch blühn im Sommer deine Boulevards / Mit Linden voll, und zittert noch im Licht / Das Elysée, wenn auf den Champ de Mars / Sich zwischen Wagen drängt die Menge dicht // Und Abend sinkt, wie Veilchen träumerisch, / Wie Veilchen welk. Der hohen Linden Duft / Weht von der Seine Ufern her, die frisch / Der Abendwind bewegt in lauer Luft. // Dann ziehn im Strom der bunten Boote viel / Am Park Vincennes vorbei, mit Immergrün / Den Mast umkränzt, und den gewundnen Kiel, / Wo, klein wie Sterne, rote Lampen glühn, // Aus niederen Spelunken schallt ein Lied, / Auf grauen Stirnen liegt der Lampe Licht / In kleinen Fenstern, die mit Laub umzieht / Ein Weinspalier, das sich im Wind verflicht. // Den Fluß hinab, durch Park und Sommergarten. / Korndampfer schaukeln in den Häfen breit, / Wo Dirnen stehn. Auf ihrem Munde warten / Die Küsse, kalt, voll herber Bitterkeit. // Doch über dir, Paris, und deiner Pracht, / Die im Verblühen noch die Brüste spreizt, / Weit über dir, und der erwachten Nacht, / Die mit Laternenschein die Straßen beizt, // Weit über deinem Haus der Invaliden, / Des schwarzes Totenmal vorüberzieht, / Glänzt wie das Bernsteintor der Hesperiden / Des Abendgottes goldnes Augenlid. [Traducción al francés en Iehl, 2012: 131].
} 
en tu regazo hondo, en un sarcófago, guardado por las alas de sus águilas, duerme el emperador, y débiles lamentos funerales vagan bajo la cúpula a medianoche,

donde como bosque se alzan las viejas banderas que arrastraron las legiones en Egipto.

Aún se oye su susurro, y el ondear de los lienzos, que suavemente envían besos a tu hijo muerto.

Pero por la mañana, al Este, sobre el Sena, como un farol de tormenta que, entre mástiles y negras barcas, ardiera en el océano, se enciende sangriento el sol sobre el oleaje urbano,

como un gran Grial, henchido de rojo vino hasta el borde, con el vino de la libertad, que persuade al corazón, y subleva, en la vasta plaza, la ira de la ciudad, que por la boca de Danton desagua.

Oh gran día aquel en que gruñeron rojos truenos sobre tu frente y echó a rodar, oronda y sangrienta, la mísera cabeza del rey por la arena, oh gran París, que envejeces y huérfano quedas;

pero aún florecen en verano tus bulevares llenos de tilos, y titila aún entre la luz el Elíseo, cuando por el Campo de Marte se adensa entre carruajes el gentío,

y se hunde la tarde, pensativa como una violeta, $\mathrm{y}$, como una violeta, marchita. De los altos tilos el aroma se impulsa desde la orilla del Sena, y fresco lo agita el viento de la tarde por el aire tibio.

Después lleva la corriente barcas coloridas frente al parque de Vincennes, coronados de perdurable fronda los mástiles, corva la quilla, con faros rojos que fulgen, diminutos, como estrellas, una canción se eleva desde el fondo de un tugurio, las lámparas posan luz sobre frentes grises tras ventanucos vestidos por la intrincada parra, que en el viento se destrenza.

Río abajo, detrás de parques y glorietas, vapores con carga de grano danzan anchos en el muelle, y no lejos andan las prostitutas. En su boca acechan, fríos, los besos, con el peso de acerba amargura.

Y sin embargo, sobre ti, París, y tu belleza, que, aun marchita, los pechos luce todavía, muy alto sobre ti, y sobre la insomne noche, que con luz de faroles macera las calles, 
muy alto sobre la cúpula de los Inválidos,

y el oscuro mausoleo a la deriva,

fulgura, puerta de ámbar de las Hespérides,

el párpado dorado del dios de la tarde. ${ }^{25}$

En este largo poema, que reúne viñetas de París en apretadas rimas de geografía e historia, despliega Heym predilecciones y habilidades antiguas: la afición al viaje imaginario, la mitificación revolucionaria, la impregnación de lo urbano por atmósfera y naturaleza, la bien gobernada embriaguez con que se suceden evocaciones emocionadas. Resulta tentador dejarse llevar por los versos como quien oye relaciones traídas por un viajero al volver de tierra extraña, y cabe presentir que esta misma gozosa facilidad con que se escande la retahíla bien podría haberse estirado docenas de estrofas más sin perder tino ni capacidad fascinadora.

El autor, atento a enlazar narrativamente las estrofas, no rehúye la coordinación adversativa (frecuentes versos se inician con un «pero»o «y sin embargo»); tampoco los símiles explícitos, mediante un «como». El propio título, «Nostalgia de París», se sitúa llanamente en el terreno de los souvenirs de viaje. ${ }^{26}$ El placer toponímico lo lleva a sembrar el poema de eufónicos nombres de lugar parisinos, que esmaltan con su sonoridad los campos del texto. No parece preocuparse de preciosismos ni encorsetarse con rigideces; tampoco busca oscurecer las imágenes. Se aprecia una fluida y desenfadada naturalidad, ajena a dogmas de estilo. Los metros clásicos le sirven de molde cómodo para una expresión que ordena eficazmente arquitecturas de emoción. Los versos se encabalgan por doquier; y hacia el final del poema, como si el crescendo dionisíaco causase hervor, desbordan con encabalgamientos de estrofa (Vollmar, 2008: 239). En el original se percibe mejor cómo consigue Heym sosegar tanta efusión en los versos finales: ocho versos de frenada componen las estrofas últimas. «Y sin embargo, sobre ti» abre una expectativa, majestuosamente ralentizada con digresiones y precisiones espaciales. La sintaxis alemana permite colocar al final de la frase, con aparatosos incisos si se desea, el predicado que pone broche. Literalmente es: «fulgura, como la puerta de ámbar de las Hespérides, / del dios de la tarde el dorado párpado». ${ }^{27}$ La mitología, como ocurre frecuentemente en Heym, es puesta al servicio de una plástica perturbadora, ajena al imaginario clásico (Mautz, 1972: 254); una mutación similar permite a las garzas, tenidas por aves de buen augurio entre los romanos, convertirse en el poema «Hora mortis» en amenazantes sombras negras.

París es celebrada en su encarnación femenina, como eterna jovencita, coqueta y casadera, entre guirnaldas nupciales, pero también como matrona, engendradora del arte, de sienes despojadas que cosméticamente recurren al laurel. No falta su caracterización como ramera de tintes babilónicos, que aun en su decadencia airea los pechos por las calles nocturnas (Rölleke, 1966: 149). La revolución es sacralizada: el rojo vino de la sangre es caldo de libertad y llena a desbordar el grial de los parisinos. El sol, también sangriento, participa en la revuelta, y confiere rasgos cosmogónicos al acontecer histórico (Luther, 1969: 77-78; Mautz, 1972: 281).

\footnotetext{
${ }^{25}$ Heym, 1964: 227; febrero de 1911.

${ }^{26}$ También cabría traducirlo como «Anhelo de París», ambigüedad oportuna: Heym no llegó a visitar la ciudad.

${ }^{27}$ El hipérbaton quedaría en español en exceso amanerado, por lo que hemos renunciado a él.
} 
LA PRIMAVERA, $\mathrm{V}^{28}$

Al borde del bosque está muriendo. Con refrenado son

ya su sombra se lamenta a la puerta del Hades.

De su cabeza cae una corona de lechugas

y rodando va entre cardos y cicuta.

Con la flecha en el cuello, suelta sangre,

su negra sangre de fauno, sobre la hierba verde

de la ladera atardeciente, por la boca

donde la muerte, polilla oscura, ya se posa.

Verde resplandece el vespertino cielo de Tracia,

y es un candelabro de plata el grito de agonía

sobre lejanas sierras donde flamean robles.

Bajo él, en lo hondo, palidece la ancha bahía,

por la altura desfilan nubes blancas,

y a lo lejos, purpúrea, una vela se desliza. ${ }^{29}$

Ensaya aquí Heym un soneto de tema y tratamiento clásicos. ${ }^{30}$ El título que figura en ediciones anteriores, «El fauno agonizante», fue sustituido por el actual, al advertir Schneider que el poema era la última pieza de una serie de cinco sonetos dedicados a la primavera (Heym, 1964: 245). Si en el primer soneto la luz matutina pisa con sandalia de plata por los campos, aquí concluye la serie con un atardecer que clausura el día y la vida de una criatura natural, el fauno. La vela purpúrea del último verso es a la vez luz del poniente y mancha de sangre. Obtiene mucha de su potencia expresiva el poema del contraste entre un solitario morir, recatado, de refrenado son, y el esplendor casi apoteósico con que se infla el paisaje al caer la tarde. Las notas cromáticas y lumínicas acompañan por doquier a la acción. Se ha subrayado la asombrosa capacidad de Heym para transponer impresiones pictóricas al verso. ${ }^{31} \mathrm{El}$ paisaje que se alza ante los ojos del lector podría ser un Poussin o un Claudio de Lorena: atardece, pero borbotea robusto con levaduras de luz.

En el aderezo vegetal de este paisaje contrastan los sobrios robles, brillantes en la lejanía, con el travieso prosaísmo de la corona de lechuga, los cardos y cicutas. Es un mundo botánico de bien calibradas correspondencias. Con solo cuatro especies evoca ámbitos paisajísticos del clasicismo mediterráneo: el monte, la huerta, el ejido y el regato, emblemas de cotidianía, compatibles con la presencia de dioses.

Los versos finales confirman la impresión de serenidad: en ellos se dibuja el viaje paralelo de nubes y veleros, en una horizontal que desliza, con amable indiferencia, fuera de la acción principal. Evocando la caída de Ícaro en un cuadro de

${ }^{28}$ DER FRÜHLING V // Er stirbt am Waldrand. Mit verhaltnem Laut / Klagt schon sein Schatten an des Hades Tor. / Der Kranz von Lattich, den sein Haupt verlor, / Fiel unter Disteln und das Schierlingskraut. // Den Pfeil im Hals, verschüttet er sein Blut, / Das schwarze Faunsblut in den grünen Grund / Der abendlichen Halde aus dem Mund / Drauf schon der Tod, ein schwarzer Falter, ruht. // Der Himmel Thrakiens glänzt im Abend grün, / Ein Siberleuchter seinem Sterbeschrei, / Auf fernen Bergen, wo die Eichen glühn. // Tief unter ihm verblaßt die weite Bai, / Darüber hoch die weißen Wolken ziehn, / Und fern ein Purpursegel schwimmt vorbei. [Traducción al francés en Iehl, 2012: 144].

${ }^{29}$ Heym, 1964: 248; marzo de 1911.

${ }^{30}$ El pentámetro yámbico, con rima, es el metro dominante en la obra de Heym. Labrando su obra dramática en verso adquirió la soltura que luego luce en los poemas (Hinck, 2004: 22, 46).

${ }^{31}$ Materia que recibe atención monográfica en Salter, 1972 y Schneider, 1954, 1967; véase también Schünnemann, 1986: 34, 104. 
Brueghel, Auden (1940: 34, «Musée des Beaux Arts») recalca el talento de la pintura clásica para reflejar la simultaneidad de lo trágico y lo ordinario, lo sublime y lo anecdótico. El remate de sus admirables versos recuerda el tratamiento que Heym da a la muerte del fauno: «the expensive delicate ship that must have seen / Something amazing, a boy falling out of the sky, / Had somewhere to get to and sailed calmly on».

\section{¿POR QUÉ VENÍS, BLANCAS POLILLAS? ${ }^{32}$}

¿Por qué venís, blancas polillas, a visitarme tanto? Vosotras, ánimas muertas, ¿por qué tan a menudo revoloteáis sobre mi mano, y la rozáis con alas que derraman por la piel un rastro de ceniza?

Vosotras vivís en las urnas, donde yacen los sueños agazapados entre eternas sombras, en crepusculares estancias, como murciélagos en sus grutas, que de noche zumbando salen con estruendo.

Durante el sueño oigo a menudo el ladrido del vampiro, carcajadas que llegan de los turbios panales de la luna, $\mathrm{y}$ atisbo candelas, al fondo de huecas cavernas, entre las sombras de los desterrados.

¿Qué es la vida?: una breve antorcha cercada por la mueca irónica de la negra tiniebla, y muchos que van llegando y extienden las manos escuálidas en torno a la llama.

¿Qué es la vida?: diminuto barco en la garganta de un mar olvidado. El terror del yerto cielo. O el vagar nocturno, sobre calvas campiñas, de extraviada luz de luna, que deambula y se pierde.

Ay de aquel que vio alguna vez morir a alguien, en el fresco silencio del otoño, cuando invisible la muerte llega al lecho húmedo del enfermo, y ordena la partida, cuando la garganta,

como de un órgano roñoso el hielo y silbo,

\footnotetext{
${ }^{32}$ WAS KOMMT IHR, WEIßE FALTER... // Was kommt ihr, weiße Falter, so oft zu mir? / Ihr toten Seelen, was flattert ihr also oft / Auf meine Hand, von euerm Flügel / Haftet dann oft ein wening Asche. // Die ihr bei Urnen wohnt, dort wo die Träume ruhn / In ewigen Schatten gebückt, in dem dämmrigen Raum / Wie in den Grüften Fledermäuse / Die nachts entschwirren mit Gelärme. // Ich höre oft im Schlaf der Vampire Gebell / Aus trüben Mondes Waben wie Gelächter, / Und sehe tief in leeren Höhlen / Der heimatlosen Schatten Lichter. // Was ist das Leben? Eine kurze Fackel / Umgrinst von Fratzen aus dem schwarzen Dunkel / Und manche kommen schon und strecken / Die magren Hände nach der Flamme. // Was ist das Leben? Kleines Schiff in Schluchten / Vergeßner Meere. Starrrer Himmel Grauen. / Oder wie nachts auf kahlen Feldern / Verlornes Mondlicht wandert und verschwindet. // Weh dem, der jemals einen sterben sah, / Da unsichtbar in Herbstes kühler Stille / [Der Tod trat an des Kranken feuchtes Bette / Und einen scheiden hieß, da seine Gurgel] // Wie einer rostigen Orgel <Frost und> Pfeifen / Die letzte Luft mit Rasseln stieß von dannen. / Weh dem, der sterben sah. Er trägt für immer / Die weiße Blume bleiernen Entsetzens. // Wer schließt uns auf die Länder nach dem Tode, / Und wer das Tor der ungeheuren Rune. / Was sehn die Sterbenden, daß sie so schrecklich / Verkehren ihrer Augen blinde Weiße? [Traducción al portugués, parcial, en Scheidl, 1985: 238, 357, 366; al francés en Iehl, 2012: 181; al inglés en Hamburger y Middleton, 1966: 161 (Middleton) y en Hasler, 2004: 130].
} 
expulsa el último aire con chirriante jadeo.

Ay de aquel que vio morir. Para siempre carga

con la blanca flor del plomizo espanto.

¿Quién nos abre los países de tras la muerte

y quién la puerta de las ingentes runas?

¿Qué es lo que ven los que mueren, qué horror

vuelca sus órbitas y deja en blanco, ciegos, sus ojos? $?^{33}$

El miedo a la muerte ${ }^{34}$ se monumentaliza y contrasta en estos versos. El dominio de la muerte se acota con radical, infranqueable distancia con respecto al de la vida (Mautz, 1972: 200). Se trata de dar concreción a terrores indefinidos, continuación de los miedos nocturnos de la infancia, que revolotean como mariposas funerales por la imaginación. Son blancas como el alma de los difuntos, pero no por impolutas, sino porque, al igual que el pelo cano o la hierba seca, han perdido la savia colorida de la vida; se deshacen como telarañas o sudarios viejos en las manos del que las toca. Los muertos yerran sin fin, en un estado de perpetuo espanto.

\section{HORA MORTIS ${ }^{35}$}

Desterrados al duelo del horizonte sin fin, donde solo un árbol de dolor se retorcía, nos hundíamos, como mineros, en el silencio de la fosa de nuestro dolor. Y el corazón se nos hinchaba de vacío.

Sumimos las manos en la sombra, tristes como el viento, buscando la cicuta, entre matos y praderas.

Y después íbamos indolentes, gozando nuestra pena, precarios espejos donde sombría la tarde refleja.

Como sonámbulos, acosados por el pavor de los sueños, que suspirando, con pálida mano, van topando en la tiniebla, así nos tambaleábamos por las menguantes salas del otoño, que, como un gigante, alzado en la noche, se desplomaba.

Pero en el país de las nubes, en lo oscuro, veíamos sombras de negras garzas y nos llegaba el son de su desconsolado vuelo, y nos borrábamos con pesadumbre, con amarga fatiga, como almas exangües, que el Leteo arrastrara por cuevas de aflicción. ${ }^{36}$

\footnotetext{
${ }^{33}$ Heym, 1964: 311; julio de 1911.

${ }^{34}$ Es tema predilecto de la Contrarreforma católica barroca, pero Heym, pese a su confesión evangélica, compite en horror con estos antecedentes, incorporando recursos de la literatura gótica.

${ }^{35}$ HORA MORTIS // Gebannt in die Trauer der endlosen Horizonte, / Wo nur ein Baum sich wand unter Schmerz, / Sanken wir, Bergleuten gleich, in das Schweigen der Grube / Unserer Qual. Und von Leere schwoll uns das Herz. // Trüb wie die Winde, im Schierling, bei Büschen und Weiden / Haben wir unsere Hände im Dunkel gesenkt, / Und dann gingen wir lässig, und freuten uns unserer Leiden, / Arme Spiegel, darin sich ein düsterer Abend fängt. // Nachtwandlern gleich, gejagt vom Entsetzen der Träume, / Die seufzend sich stoßen im Dunkel mit <bleicher> Hand, / Also schwankten wir in des Herbstes verschwindende Räume, / Der wie ein Riese sich hob in die Nacht und versank. // Aber im Wolkenland, im Finstern, sahn wir die Schatten / Schwarzer Reiher und hörten den traurigen Flug, / Und wir schwanden dahin in Schwermut und bittrem Ermatten, / Blutleere Seele, die Lethe durch Höhlen voll Kummer trug. [Traducción al portugués, parcial, en Scheidl, 1985: 358, 367; al francés en Iehl, 2012: 187].

${ }^{36}$ Heym, 1964: 320; agosto de 1911.
} 
De nuevo, como en múltiples pasajes de Heym, el yo poético se desdibuja tras un plural en el que no cabe sospechar un sentido social y colectivo (Sprengel, 2004: 663; Mautz, 1972: 117, 121, 129). La aflicción personal se vuelve absoluta e impersonal. La repulsa al presente histórico, a sus ciudades inhumanas y su sociedad maquinal, impone una odisea compartida y confusa, dilatada por titánicas lejanías: el destierro es planetario y la infelicidad se vuelve epopeya. Durand-Henriot (2000: 377) ve en estos plurales heymianos un eco de su sentimiento desbordado por la inmensidad del cosmos. Los horizontes sin término del primer verso parecen exigir, como el firmamento pide estrellas, la pluralidad de las conciencias. El caminar errabundo es sugerido por la métrica vacilante, en la que alternan trocaicos y yámbicos, en versos de cinco pies (Scheidl, 1985: 377). En lo temático, el poema enlaza con otros en que se aborda el suicidio o la vida de los muertos bajo los trazos de una oscura empresa común.

\section{A LA MUERTE DE LOS PRADOS ENMUDECIERON LOS CORNOS DEL ESTÍO ${ }^{37}$}

A la muerte de los prados enmudecieron los cornos del estío y pasando hacia la penumbra, bogó nube tras nube: pero descarriados se acurrucaban los bosques a la ronda, como séquito de féretros, embozados en luto.

A voces cantó la tormenta sobre el pavor de los campos lívidos, embistió contra los chopos y cimbreó la blanca torre. Y abajo quedó tendida, en el yermo, una aldea, montón de tejados grises, como barredura del viento.

Pero allá adelante hasta el gris del cielo, iban irguiéndose, de grano, los pabellones del otoño, y ciudades incontables, mas sin gente, olvidadas.

Y nadie andaba por las callejas.

Y las sombras de la noche cayeron. Solo los cuervos vagaban aún bajo las nubes graves, entre la lluvia, solos en el viento, como se desbandan desde sienes sombrías los pensamientos oscuros en las horas de desconsuelo. ${ }^{38}$

El silencio de las ciudades deja campo musical al estío, con sus cornos. La tormenta impetuosa, que embiste a la vez que canta, los enmudece, para luego ser

37 Und DIE HÖRNER DES SOMMERS VERSTUMMTEN... // Und die Hörner des Sommers verstummten im Tode der Fluren, / In das Dunkel flog Wolke auf Wolke dahin. / Aber am Rande schrumpften die Wälder verloren, / Wie Gefolge der Särge in Trauer vermummt. // Laut sang der Sturm im Schrecken der bleichenden Felder, / Er fuhr in die Pappeln und bog einen weissen Turm. / Und wie der Kehricht des Windes lag in der Leere / Drunten ein Dorf, aus grauen Dächern gehäuft. // Aber hinaus bis unten am Grauen des Himmels / Waren aus Korn des Herbstes Zelte gebaut, / Unzählige Städte, doch leer und vergessen. / Und niemand ging in den Gassen herum. // Und es sank der Schatten der Nacht. Nur die Raben noch irrten / Unter den drückenden Wolken im Regen hin, / Einsam im Wind, wie im Dunkel der Schläfen / Schwarze Gedanken in trostloser Stunde fliehn. [Traducción al portugués en Barrento, 1976: 145; al francés en Iehl, 2012: 187; al inglés en Hamburger y Middleton, 1966: 153 (Hamburger)].

${ }^{38}$ Heym, 1964: 321; agosto de 1911. 
desalojada al caer el telón sombrío de la noche. ${ }^{39}$ En esta sucesión de voces, lo humano ha sido barrido y vaciado por una naturaleza sin remordimientos. La recurrente voluntad narrativa en la poesía de Heym conduce a personificar (viento, cuervos, noche) las pulsiones anímicas (Mautz, 1972: 94). El poema se relata en pasado, enlazando con adversativas y copulativas, más o menos caprichosas, las oraciones; el verso inicial enmarca el poema en otoño. ${ }^{40}$ Los cuervos finales, negros como los pensamientos de aflicción, con sus vuelos erráticos entre nubes, recuerdan el célebre cuadro de Van Gogh, «Trigal con cuervos», de $1890 .^{41}$

\section{LOS NAVEGANTES ${ }^{42}$}

Las frentes de las naciones, rojas y nobles como coronas, vimos hundirse lejos, entre el desplomarse del día, y en su trono las murmurantes guirnaldas de los bosques, bajo el batir atronador de las alas del fuego.

Para ennegrecer con luto los árboles chasqueantes, bramaba la tormenta. Se consumían, como si tuvieran sangre, en su remoto morir. Como se alza sobre el corazón agonizante, por una última vez, el ascua ardiente del amor.

Pero nosotros seguíamos, allá sobre el mar poniente, arreboladas las manos como candelas. Y dentro se veían las venas, y la densa sangre a contrasol, fluyendo sorda hacia los dedos.

La noche empezaba. Alguien lloraba en la sombra. Bogábamos sin fe, con oblicuas velas, hacia la distancia.

Pero sobre la cubierta nos apiñábamos silenciosos a escrutar la tiniebla. Y toda luz nos flaqueaba.

Solo una nube perduraba lenta a lo lejos, al borde de la noche, en el espacio eterno, flotando purpúrea, como cuando se alza hermosa sobre el sonoro abismo del alma la voz de un sueño. ${ }^{43}$

39 Una edición anterior (Heym, 1922: 193) lee «sang» en vez de «sank» en el verso decimotercero. Ello permite enlazar con la tormenta cantora del verso anterior: «y la sombra de la noche cantaba».

${ }^{40}$ Título que algunos editores adoptan para el poema, «Der Herbst» (Schneider, 2000: 158).

${ }^{41}$ De Van Gogh dice Heym «ve todos los colores como yo los veo» (Heym, 1960: 205, en Schünemann, 1986: 34).

42 DIE SEEFAHRER // Die Stirnen der Länder, rot und edel wie Kronen / Sahen wir schwinden dahin im versinkenden Tag / Und die rauschenden Kränze der Wälder thronen / Unter des Feuers dröhnendem Flügelschlag. // Die zerflackenden Bäume mit Trauer zu schwärzen, / Brauste ein Sturm. Sie verbrannten, wie Blut, / Untergehend, schon fern. Wie über sterbenden Herzen / Einmal noch hebt sich der Liebe verlodernde Glut. // Aber wir trieben dahin, hinaus in den Abend der Meere, / Unsere Hände brannten wie Kerzen an. / Und wir sahen die Adern darin, und das schwere / Blut vor der Sonne, das dumpf in den Fingern zerrann. // Nacht begann. Einer weinte im Dunkel. Wir schwammen / Trostlos mit schrägem Segel ins Weite hinaus. / Aber wir standen am Borde im Schweigen beisammen / In das Finstre zu starren. Und das Licht ging uns aus. // Eine Wolke nur stand in den Weiten noch lange, / Ehe die Nacht begann, in dem ewigen Raum / Purpurn schwebend im All, wie mit schönem Gesange / Über den klingenden Gründen der Seele ein Traum. [Traducción al francés en Iehl, 2012: 198; al inglés en Forster, 1967: 434, en Hasler, 2004: 138 y en Washburn, Major y Fadiman (1998: 809) (Christopher Benfey)].

${ }^{43}$ Heym, 1964: 339; 3 de septiembre de 1911. 
Son varios los poemas de navegación fantástica que llegó a escribir Heym. En ellos se percibe una antigua deuda con los libros de aventura, y ecos de Salgari y Poe. Esta inspiración primaria se ve enriquecida por lecturas posteriores, tal los poemas marítimos de Baudelaire y el «Bateau îvre» de Rimbaud (Krüger, 1993: 242; Mautz, 1972: 174, 179). Como ocurre en otros poemas de Heym que se alejan del canon expresionista (los de ambientación exótica o clasicista, los amorosos, los paisajísticos), ha recibido menor atención crítica.

La ambigüedad del «Länder» inicial (geográfico: países, tierras; pero también político: naciones) preserva el plano metafórico, familiar en Heym, de la revolución y el derrocamiento de testas coronadas. El incendio que devora lejanas orillas es el de un mundo en ebullición por fuerzas demoníacas o subversivas. Múltiples correspondencias cohesionan el sistema de imágenes. El sol ilumina al trasluz las manos de los marinos, ${ }^{44}$ asumiendo la inquietante función de un aparato de rayos $\mathrm{X}$; el cuerpo incendiado es un eco de los lejanos árboles que arden; la lentitud de la sangre en las venas tiene la misma morosidad, irresoluta y extraviada, del barco sin rumbo.

Como es común en Heym, el poema no renuncia a extraer explícitamente analogías que, escapando del plano descriptivo-metafórico, ofrecen diagnóstico sobre la condición humana. En ambos casos (estrofas segunda y quinta), la transición viene marcada por un término de comparación: «como». La crítica ha censurado ocasionalmente la explicitud de la moraleja, pero preferimos ver en ello un signo más de la constante aspiración a la sencillez y llaneza en Heym, que también se hace notar en el vocabulario elegido, ajeno al registro preciosista o intelectual.

La sinestesia final convierte una nota de color, la nube purpúrea, en un acento sonoro. Esta conversión tematiza la portentosa capacidad del poeta para evocar el arte pictórico a través del lenguaje. Un don que celebra Ernst Ludwig Kirchner cuando, en 1924 , ilustra con robustas xilografías este y otros textos del libro póstumo Umbra Vitae.

\begin{abstract}
MITAD DEL INVIERNO ${ }^{45}$
El año sucumbe resentido. Y días tenues se desperdigan como cabañas en invierno. Y noches, sin lumbres y sin horas, y de mañanas grises, estampas borrosas.

Veranos, otoño, todo pasa a la deriva, y la parda muerte ha cosechado toda fruta. Otros arbustos fríos esconde la sombra, que de lo alto de los barcos no avistamos.
\end{abstract}

Sin rumbo es toda vida. Y todo sendero enmarañado. Y nadie conoce el final:

\footnotetext{
${ }^{44}$ Ello presupone un rumbo hacia el oeste (los marineros dirigen la vista al ocaso, esforzándose por ver tierra), lo cual enlaza este poema con el bellísimo «Colón» (Heym, 1964: 218), del que existe traducción al español (Armas, 2018: 103).

${ }^{45}$ MitTE DES WINTERS // Das Jahr geht zornig aus. Und kleine Tage / Sind viel verstreut wie Hütten in den Winter. / Und Nächte, ohne Leuchte, ohne Stunden, / Und grauer Morgen ungewisse Bilder. // Sommerzeit. Herbstzeit, alles geht vorüber / Und brauner [Tod] hat jede Frucht ergriffen. / Und andre kalte <Stauden> sind im Dunkel / Die wir nicht sahen von dem Dach der Schiffe. // Weglos ist jedes Leben. Und verworren / Ein jeder Pfad. Und keiner weiß das Ende, / Und wer da suchet, daß er Einen fände, / Der sieht ihn stumm, und schüttelnd leere Hände. [Traducción al portugués, parcial, en Scheidl, 1985: 113, 236; al francés en Iehl, 2012: 248; al inglés en Bridgwater, 1963: 111 y en Wilmer, 1982: 47].
} 
el que se afana en encontrar a Uno,

alcanzándolo lo ve mudo, y vacías las manos. ${ }^{46}$

Este inspirado esbozo de los meses finales se organiza en endecasílabos; las dos primeras estrofas, con rima asonante en los versos impares; la tercera estrofa, buscando un cierre tajante, sitúa la rima, en parte consonante, en los tres últimos versos. Las equivalencias entre clima, biografía e historia están tan bien acuñadas y circuladas ya en la obra de Heym, que no le es preciso enfatizarlas. El desorden de las estaciones es asimilado a la deriva de restos de naufragio. Las frases aparecen en staccato, sin la trabazón discursiva de poemas anteriores. Weissenberger (2005: 198) ve en ello una referencia a una sociedad que pierde su eje cosmogónico, su anclaje en la progresión heroica. Las estaciones se suceden caóticas, sin la impronta de lo festivo, que antes ejercía una función ordenadora y narrativa en la historia, gracias a su capacidad de restablecer «magical or mythic time and to reaffirm communal identity, to provide structure, meaning, and a mythic sense of belonging». El tiempo se desarticula: los días dispersos como las cabañas desperdigadas en los pastos de montaña, las noches sin luces ni señales, las mañanas grises e indistintas. El año, que se extingue colérico, ofrece una perfecta inversión del clímax navideño. La estación próvida, el otoño, se malogra y es la muerte marrón - color que alude a lo putrefacto- quien cosecha los frutos.

En los dos versos de cierre ha reconocido Mautz (1972: 154) una parodia del poema «Otoño» de Rilke: «pero hay Uno que en las manos retiene, / con indecible blandura, esta caída». ${ }^{47}$ Aquí este consuelo se disipa: la figura salvadora, de contornos religiosos, se sacude las manos vacías.

Ha provocado discusión una palabra, oscura en el original, del séptimo verso. Schneider lee «Stauden» «matojos» (Heym, 1964: 438); ediciones anteriores proponían «Sternen» «estrellas». Evidentemente, una lectio facilior pide estrellas: constelaciones frías (el calificativo se amolda perfectamente), que se esconden en una distancia invisible, ocultando rumbos para una humanidad extraviada. Mautz (1972: 153) se suma a esta lectura, al percibir otro eco paródico, el de unos versos de Hofmannsthal, «otros residen junto al timón, arriba, / conocen el vuelo de las aves y el país de las estrellas». ${ }^{48}$ Heym invierte esta posición omnisciente: desde lo alto de los barcos también hay ceguera; el sabio tampoco sabe. Más ardua es la tarea de integrar la lectura «Stauden», palabra decididamente antipoética y cargada de connotaciones divergentes en español (ella y sus equivalencias: mata, planta vivaz, matorral). Mager Hois (2009: 6) ha propuesto vincular este término a la fruta malograda del verso anterior. Hay más naturaleza, más matorral con posibles bayas y otras recompensas, pero no se deja ver, agazapada como está, desde lo alto del buque.

${ }^{46}$ Heym, 1964: 438; esbozo, octubre de 1911.

47 «Und doch ist Einer, welcher dieses Fallen / unendlich sanft in seinen Händen hält» (Rilke, 2018: 24). Heym tilda a Rilke de «lechuguino pragués» («Prager Gecken») (Heym, 1962: 181).

${ }^{48}$ Del poema «Manche freilich...» [1895-1896]. Por otra parte, sugiere Mautz, la proliferación de frases que empiezan con la copulativa «Und» parece evocar otro poema de Hofmannsthal, «Ballade des äußeren Lebens» [1894]. 


\section{LA SILUETA DE LOS TEJADOS ${ }^{49}$}

La silueta de los tejados y un canto perdido de pájaro en el espacio, cansado de la lluvia.

Que sale por la amarilla noche flotando.

Callados están los patios y como difuntos.

Una ventana se cierra. Y se distinguen palabras, y se dispersan. $\mathrm{Y}$ largos pasos rozan, y apagado eco susurra en las paredes, y el doliente pesar tras largas horas.

Mugiente bate un reloj la medianoche desde casas, atravesando muros, al vacío. Y la lluvia llama con oblicuos dedos de dolor en los vitrales negros, mansa. ${ }^{50}$

Un nocturno de ciudad bajo la lluvia: la descripción encadena imágenes en sordina, preñadas de avisos inquietantes. La lluvia, el pájaro, los murmullos, los golpes de reloj son otros tantos emisarios desde la vida humana a un espacio de negra indiferencia. El original presenta una tal vez buscada ambigüedad: ¿quién está cansado, quién sale flotando -el pájaro, su canto, el espacio-? En la vaguedad de la noche, sus pobladores son invisibles; solo suenan vestigios: cantos, palabras, pasos. Un mundo sin rostro, salvo el del reloj, redondo y maquinal.

\section{EL CAMPO ESTÁ CUBIERTO DE CIUDADES MUERTAS ${ }^{51}$}

El campo está cubierto de ciudades muertas, y como guirnalda cuelga la hiedra en las almenas.

$\mathrm{Y}$ a veces una campana llama desde dentro, y el turbio río lengüetea los muros.

Bajo una vaga luz, errante desde las nubes, avanzan al atardecer afligidas cohortes por caminos rasos, envueltas en negro velo, llevando en las manos marchitas flores.

Fuera se agolpa, en la descarriada estepa, apocado gentío al borde de las hondas fosas.

${ }^{49}$ DER DÄCHER SCHATTENRISSE... // Der Dächer Schattenrisse, und verloren / Ein Vogelruf im Raum, dem regenmüden. / Der flattert in die gelbe Nacht vorauf. / Still sind die Höfe und wie abgeschieden. // Ein Fenster tut sich zu. Und Worte [fallen], / Und sind verweht. Und lange Schritte streifen, / Und mattes Echo flüstert in den Mauern, / Und langer Stunden schmerzliches Bedauern. // Blechern schlägt eine Uhr die Mitternacht / In Häusern durch die Wände in den Tiefen. / Und Regen schlägt mit seinen Fingern, schiefen, / Aus Trübsal an die schwarzen Scheiben sacht. [Traducción al francés en Iehl, 2012: 250].

${ }^{50}$ Heym, 1964: 443; octubre de 1911.

${ }^{51}$ VON TOTEN STÄDTEN IST DAS LAND BEDECKET... // Von toten Städten ist das Land bedecket, / <Wie> Kränze hängt der Efeu von den Zinnen. / Und manchmal eine Glocke rufet innen. / Und trüber Fluß rundum die Mauer lecket. // Im halben Licht, das aus den Wolken schweifet, / Im Abend gehn die traurigen Geleite / Auf Wegen kahl, in schwarzen Flor geschlagen, / Die Blumen trocken in den Händen tragen. // Sie stehen draußen in verlorner Weite, / Ein Haufe schüchtern bei den großen Grüften. / Noch einmal weht die Sonne aus den Lüften, / Und malt wie Feuer rot die Angesichter. [Traducción al francés en Iehl, 2012: 266]. 
Otra vez el soplo del sol cruza los aires,

y pinta como de fuego rojos los semblantes. ${ }^{52}$

Parece augurar el surrealismo este poema que invierte los papeles de ciudad y campo. A un lado, las ciudades, numerosas y vacías: Rölleke (1966: 120) muestra la polisemia del epíteto: ciudad sin vida, ciudad de los muertos. El antiguo orden, socavado por la historia, ya solo es un cascarón tenebroso, del que llegan campanadas cuyo lenguaje se ha perdido irremediablemente. Envolviéndolas, un campo informe, llano, extraviado, donde yerran muchedumbres enigmáticas. Podrían ser legiones guerreras o cortejos fúnebres; se avisa de su carácter tímido e irresoluto. Pero el sol, figura central en el mito revolucionario de Heym (Mautz, 1972: 270), lanza sus soflamas rojas sobre este público descabezado. Como en otros poemas del autor, el texto adquiere estatura profética: aquí está retratada la futura Polonia de ciudades destruidas, marchas de la muerte, ingentes fosas y muchedumbres aventadas desde los campos de exterminio.

\section{CONTRA LOS JUDÍOS DE LA ROPA ${ }^{53}$}

No puedo pasear ya con mi pena

- por todas partes veo a los ropavejeros, de grandes cabezas y oreja al viento-,

el sol rosado brilla en flecos fragantes.

En la esquina de la calle Tauentzien, donde vivía mi amada, ay la Elenita Franke, a quien tanto he querido.

Allí en el revuelo de las putas, entre tirabuzones y tenderetes, pasan las tardes de seis a siete, pilas de roña, restos de antaño.

Sus voces me zumban en la cabeza como redoble febril de tambor viejo, abren los brazos para cerrarme el paso.

En mi alma menuda pellizca gigante tijera.

Para lo excelso tienen la mente tapiada y candada con pesados cerrojos.

Solo frufrú de ropa habita sus sueños, mohosos y opacos en la caja de las frentes.

\footnotetext{
${ }^{52}$ Heym, 1964: 471; noviembre de 1911.

${ }^{53}$ GEGEN DIE KLEIDERJUDEN // Keinen Weg mehr kann ich traurig gehen / Überall sehe ich die Kleiderjuden stehen / Mit riesigen Köpfen und Ohren steil in die Luft, / Rosige Sonne glänzt in den Zipfeln voll Duft. // An der Ecke der Tauentzienstraße, / Wo meine Liebste gewohnt, / Ach die Lenchen Franke, / Die ich so sehr geliebt, // Dort im Gewühle der Nutten / Bei Löckchen und winzigen Hüten / Stehn sie abends von sechs bis um sieben, / Rostige Säulen, von alters geblieben. // Ihre Stimmen quarren mir wild im Kopfe / Rasselnd wie alter Trommeln Geklopfe, / Ihre Arme sperren sie aus, mir zu wehren. / Meine Seele, die kleine, zwickt es mit riesigen Scheren. // Für Höheres sind ihre Sinne verriegelt / Und verhänget mit schweren Siegeln, / Nur von den Kleidern die Träume säuseln / <Murmelig> dumpf in der Stirnen Gehäusen. // Wenn sie einmal verscheiden, werden sie Motten / Wohnend in Schränken und modrigen Truhen. / Bohrend in altem Rock die verschlungenen Grotten, / Winters unten im Dunkel zu ruhen. [Traducción al francés en Iehl, 2012: 278].
} 
Cuando un día mueren, se vuelven polillas

y habitan armarios y arcas purulentas.

Taladran en las viejas levitas torcidas grutas,

para a la sombra reposar en invierno. ${ }^{54}$

Sorprende en la producción heymiana este dicterio en verso, que, con el desolador conocimiento actual de lo que luego vendría, podría alarmarnos. El poeta, jovial conmilitón de alguna belicosa hermandad estudiantil, ${ }^{55}$ estuvo sin duda expuesto a un ambiente donde eran moneda corriente los hostigamientos y desafueros contra un escalón social ocupado no por los judíos integrados de la culta y alta burguesía, sino por los otros judíos, inmigrantes pobres y exóticos de origen eslavo. ${ }^{56} \mathrm{La}$ crítica ha desactivado en parte esta línea de exploración, situando el poema en el terreno de las humoradas juveniles y la sátira contra el espíritu sofocantemente comercial (Versluys, 1987: 105): invectiva extrapolable a familias cristianas de cerrada mollera mercachifle. Heym contó entre su círculo próximo de amistad a artistas judíos, como Erwin Loewenson, Heinrich E. Jacob o David Baumgardt; su propia amiga o novia de los últimos meses, la judía Hildegard Krohn, perece en 1942 en un campo de exterminio.

El poema, por su tono y esquema métrico, se funde en moldes del cancionero popular, y debe mucho a la poesía ligera, ágil y zumbona de Heine. Ya en la estrofa inicial se parodia la musa convencional del estudiantón, que se echa a las calles de Berlín a paladear penas de amor mientras el sol poniente colorea la ciudad. Este intento es frustrado por una obstinada intrusión, en forma de dos versos anticlimáticos que se instalan en el centro de la estrofa: por doquier los ropavejeros, con su crudo ensalmo comercial. «[D]ie Lenchen Franke», un amorcito pasajero de Heym, por nombre y contexto, parece también judía.

Cabe comparar las polillas de la última estrofa, reencarnación burlesca de los viejos comerciantes que han pasado la vida entre rancia ropa, con las blancas mariposas del poema «¿Por qué venís, blancas polillas?». Heym marca una diferencia léxica (Motten / Falter), distinción que no hemos preservado en estas versiones. Ambas, polillas o mariposas, revolotean en las pesadillas del poeta como emanación de ultratumba, fuegos fatuos que se elevan sobre su terrorífica imagen de la muerte; pero en este poema, de intención jocosa, son amables y cómicos trasuntos del industrioso comerciante.

\footnotetext{
${ }^{54}$ Heym, 1964: 493; diciembre de 1911.

${ }^{55}$ En ello (y en adornar su cara con alguna prestigiosa cicatriz de esgrima) sigue a su inspirador Nietzsche. Algunas corporaciones fueron semilleros de nacionalsocialismo.

${ }^{56}$ En sus diarios, anota: «mi postura ante los judíos es la siguiente: me siento a priori, por instinto racial, hostil y en contra; no lo puedo evitar. Pero he conocido tantos ejemplares majos, incluso encantadores, de la raza semítica (Guttmann, Baumgardt, Wolfsohn), que por pura racionalidad le he echado el freno a mi juicio» (Heym, 1960: 150). La arremetida contra los ropavejeros judíos se inserta en una hostilidad antisemita de largo recorrido. Ya en la Revolución de Marzo de 1848 hubo algaradas amenazantes del populacho contra los judíos roperos (Denkler, 1983: 249). El romántico Achim von Arnim incurre en fantasías a medio camino entre el humor y el escarnio a propósito de ellos (Oesterle, 1992: 61).
} 


\section{LAS CIUDADES $^{57}$}

Agazapadas al caer la tarde calles fragosas en ciudades en sombra, un tropel de perros ladrando al vacío. Y sentíamos pasar grandes carruajes sobre los puentes,

el temblor de voces barridas por el aire. $\mathrm{Y}$ ojos redondos nos miraban tristes, y extensas caras, y el moroso andar de la risa desde sus frentes taimadas.

Pasaron dos, con amarillos mantos, llevando en vilo nuestras cabezas, regadas de sangre, y en las huecas mejillas un rojo postrero aún por secar.

Despavoridos huíamos. Pero un río de blancas olas nos cerraba el paso enseñando los dientes.

$Y$ tras nosotros el fiero sol poniente hostigaba con atroz espada calles muertas. ${ }^{58}$

Lo apocalíptico se combina con lo revolucionario en un ensamblaje onírico entre paisajes de fin del mundo y evocaciones del terror político. El sol poniente ejerce funciones de espada flamígera, y funde su color, rojo revolucionario, con el de la sangre de la guillotina. El río es personificado, y sus olas, que rompen, son dientes de perro regañón. La ciudad se trastorna: teatro de algaradas, recorrido por un vago agente colectivo, con carreras y retrocesos.

Como en otros poemas, convive la indefinición con los crueles detalles. ¿Por qué son dos los verdugos? Análogamente, en «El llano», son tres las nubes y tres los hachones funerales. La precisión incompleta es un recurso que patetiza la expresión: un oscuro testigo recuerda fragmentos, que, por su aparente irrelevancia, no pueden ser mentira. A la inversa, es confuso el «nosotros», así como la pluralización de «ciudades»: la acción evidentemente transcurre en una sola ciudad, pero se desdibuja en la indiferencia de una simultánea y multiplicada hecatombe. El poeta renuncia a retratar una ciudad particular, ofreciendo del paisaje urbano lo más anónimo y genérico: calles, puentes, carruajes (Mautz, 1972: 122).

En la segunda estrofa se caracteriza a una muchedumbre que, lejos de cualquier exaltación de las virtudes del pueblo, asume los rasgos de la pasividad aborregada y alevosa. Es el mismo «apocado gentío» de un poema anterior.

${ }^{57}$ DIE STÄDTE // Der dunkelnden Städte holprige Straßen / Im Abend geduckt, eine Hunddeschar / Im Hohlen bellend. Und über den Brücken / Wurden wir große Wagen gewahr, // Zitterten Stimmen, vorübergewehte. / Und runde Augen sahen uns traurig an / <Und> große Gesichter, darüber das späte / Gelächter von hämischen Stirnen rann. // Zwei kamen vorbei in gelben Mänteln, / Unsre Köpfe trugen sie vor sich fort / Mit Blute besät, und die tiefen Backen / Darüber ein letztes Rot noch verdorrt // Wir flohen vor Angst. Doch ein Fluß weißer Wellen / Der uns mit bleckenden Zähnen gewehrt. / Und hinter uns feurige Abendsonne / Tote Straßen jagte mit grausamem Schwert. [Traducción al español, recurso en línea, en Armas, 2016; al portugués, parcial, en Scheidl, 1985: 128; al francés en Iehl, 2012: 279].

${ }^{58}$ Heym, 1964: 494; segunda versión, mitad de diciembre de 1911. 


\section{LOS CASTILLOS $^{59}$}

De sangre vieja, y llenas las muertas fauces, mascan tiniebla donde espadones brillaron.

Turbia farra, de noche, en los corros reales.

Afuera el sol aún dispara los tardíos rayos.

Nosotros íbamos también. Por pasarelas y pasillos; algún cortinaje se descorría y volvía a abatirse.

Muchas sombras sobre hiladas de tablones pálidos nos venían a los pies como perros al reposo.

Sobre los sombríos enlutados patios, entonaban arriba veletas la chirriante canción de la tarde.

$\mathrm{Y}$ en la alta luz, de los dioses los atalajes

veloces rodaban lejos hacia el festivo sur. ${ }^{60}$

Poema portentoso de los últimos días de Heym, concebido durante su viaje a Metz (Schneider, 2000: 194). La descripción teje un erizado sistema de alusiones metafóricas. El vetusto Medioevo habita aún, como un escalofrío tenaz, la carcasa ennegrecida del castillo: el plural del título responde al impulso totalizador de la expresión, como en «Las ciudades». El tratamiento de la historia, fluido a presión que infla y conforma la arquitectura, puede recordar las Neue Gedichte de Rilke. Las sombras que buscan amo, como perros sin dueño, convierten al siempre borroso «nosotros» poético en una imperiosa comitiva feudal. Una maquinaria ciega, la de las veletas, emite algo que el poeta declara como canción: monotonía que habla un lenguaje no humano (Mautz, 1972: 244). La estrofa final cierra el poema con un majestuoso movimiento ascendente, hacia un cielo agitado por donde transitan los carruajes de los dioses.

\section{CONCLUSIÓN}

Las letras universales habrían sido otras si la activa guadaña no hubiera sido tan diligente en segar las vidas de algunos grandes, enmudeciéndolos en plena apoteosis. Reeditar con sutiles toques la historia de estos autores bastaría para coleccionar prodigiosas consecuencias: si la tuberculosis no hubiera raptado a Keats en la cima de su esplendor, si los plazos de la parca hubieran autorizado a Jane Austen terminar aunque solo fuera una novela más, si la capa de hielo invernal en el río Havel hubiese esperado unas horas para crujir y romperse aquel 16 de enero en que Georg Heym y Ernst Balcke decidieron salir a patinar. Por ello, un espigueo en la -así y todo copiosa - producción heymiana puede servir de consoladora excursión hacia los mundos posibles. En la diversidad de los poemas seleccionados en esta breve muestra afloran cabos sueltos, no pocos de ellos ajenos al canon expresionista, que dejan

${ }^{59}$ DIE SCHLÖSSER // Alt von Blute, und manches im toten Munde / Kauen sie <Dunkel>. - Wo große Schwerter geblitzt. / Trübe Gelage zur Nacht in der Könige Runde - / Draußen die Sonne die späten Pfeile noch spritzt. // Wir auch gingen herum. Und kamen durch Stiegen und Gänge. / Mancher Vorhang tat sich auf und fiel zu. / Viele Schatten auf bleichen Dielen in Länge / Kamen um unseren Fuß wie Hunde in Ruh. // Über den Höfen, den dunklen voll <Trauer>, begannen / Windfahnen oben das knarrende Abendlied. // Und hoch in dem Licht der Götter große Gespanne / Schnelle rollten dahin in den festlichen Süd. [Traducción al francés en Iehl, 2012: 288].

${ }^{60}$ Heym, 1964: 510; diciembre de 1911 a enero de 1912. 
adivinar tentaciones, potencias y visiones que tal vez habrían fulgurado en feliz floración en tiempos ulteriores a los cataclismos del poeta y los apocalipsis de su época.

\section{OBRAS CITADAS}

Armas, Montserrat (ed.) (2016, 3 de marzo), «El yo y la gran ciudad. El Expresionismo romántico. Georg Heym +3 poemas», en Vallejo \& Co., <www. vallejoandcompany.com/el-yo-y-la-gran-ciudad-el-expresionismo-romantico-georgheym-3-poemas>.

Armas, Montserrat (ed.) (2018), El día eterno. Georg Heym, Madrid, Trotta.

Asser, Bodo (1973), Der Raum in der Erzählkunst: Wandlungen der Raumdarstellung in der Dichtung des 20. Jahrhunderts, Tubinga, Universidad.

Auden, Wystan H. (1940), Another Time, Nueva York, Random House.

Barrento, João (1976), Expressionismo alemão. Antologia Poética, Lisboa, Ática.

Bridgwater, Patrick (ed.) (1963), Twentieth-Century German Verse, Penguin Books.

Denkler, Horst (ed.) (1983), Adolf Streckfuß. 1848, die März-Revolution in Berlin: ein Augenzeuge erzählt, Berlín, C. W. Leske.

Durand-Henriot, Isabelle (2000), Magie et temporalité dans les poèmes sarmates de Johannes Bobrowski: La réception d'Oskar Loerke et de Peter Huchel, Vileneuve d'Ascq, Presses universitaires du Septentrion.

Forster, Leonard (ed.) (1967), The Penguin Book of German Verse, Bungay, The Chaucer Press.

Hamburger, Michael P.L. y Christopher Middleton (eds.) (1966), Modern German Poetry, 1910-1960: an Anthology with Verse Translations, Londres, MacGibbon \& Kee.

Hasler, Antony (ed.) (2004), Georg Heym. Poems, translated with introduction and notes, Londres, Libris.

Heym, Georg (1922), Dichtungen, Múnich, Kurt Wolff.

Heym, Georg (1960), Dichtungen und Schriften. Tagebücher, Träume, Briefe, vol. 3, ed. Karl Ludwig Schneider, Hamburgo-Múnich, Heinrich Ellermann.

Heym, Georg (1962), Dichtungen und Schriften. Prosa und Dramen, vol. 2, ed. Karl Ludwig Schneider, Hamburgo-Múnich, Heinrich Ellermann.

Heym, Georg (1964), Dichtungen und Schriften. Lyrik, vol. 1, ed. Karl Ludwig Schneider, Hamburgo-Múnich, Heinrich Ellermann.

Hinck, Walter (2004), Zerbrochene Harfe: die Dichtung der Frühverstummten. Georg Heym und Georg Trakl, Bielefeld, Aisthesis-Verlag.

Iehl, Dominique (ed.), (2012), Georg Heym. Oeuvre poétique 1910-1912, París, L'Harmattan.

Korte, Hermann (1982), Georg Heym, Stuttgart, Metzler.

Krüger, Eva (1993), Todesphantasien: Georg Heyms Rezeption der Lyrik Baudelaires und Rimbauds, Fráncfort, P. Lang.

Leipelt-Tsai, Monika (2015), Aggression in lyrischer Dichtung: Georg Heym - Gottfried Benn Else Lasker-Schüler, Bielefeld, Transcript Verlag.

Luther, Gisela (1969), Barocker Expressionismus?: Zur Problematik der Beziehung zwischen der Bildlichkeit expressionistischer und barocker Lyrik, La Haya-París, Mouton.

Machado, Antonio (1989), Poesía y prosa. Tomo II. Poesías completas, ed. Oreste Macri, Madrid, Espasa-Calpe.

Mager Hois, Elisabeth Albine (2009), «Überwindung von Persönlichkeitsproblemen an Hand von Literarischen Texten», IX Encuentro AMPAL Centro de Estudios y Certificación de Lenguas Extranjeras. Universidad Autónoma de Nuevo León (UANL), Monterrey, 13.9.2009.

Mautz, Kurt (1972), Georg Heym: Mythologie und Gesellschaft im Expressionismus, Fráncfort, Athenäum.

Oesterle, Günter (1992), «Juden, Philister und romantische Intellektuelle. Überlegungen zum Antisemitismus in der Romantik», Athenäum. Jahrbuch für Romantik, 2, pp. 55-90.

Rilke, Rainer Maria (2018), Das Buch der Bilder, Fráncfort, Outlook. 
Rölleke, Heinz (1966), Die Stadt bei Stadler, Heym und Trakl, Berlín, Erich Schmidt.

Salter, Ronald (1972), Georg Heyms Lyrik: Ein Vergleich von Wortkunst und Bildkunst, Múnich, Fink.

Scheidl, Ludwig (1985), O pré-expressionismo na literatura alemã: Georg Heym, Georg Trakl, Ernst Stadler, Coímbra, Universidade.

Schneider, Karl Ludwig (1954), Der bildhafte Ausdruck in den Dichtungen Georg Heyms, Georg Trakls und Ernst Stadlers, Heidelberg, Winter.

Schneider, Karl Ludwig (1967), Zerbrochene Formen: Wort und Bild im Expressionismus, Hamburgo, Hoffmann und Campe.

Schneider, Nina (2000), Am Ufer des blauen Tags. Georg Heym: sein Leben und Werk in Bildern und Selbstzeugnissen, Basilea, Böckel.

Schünemann, Peter (1986), Georg Heym, Múnich, C. H. Beck.

Sprengel, Peter (2004), Geschichte der deutschsprachigen Literatur, 1900-1918: von der Jahrhundertwende bis zum Ende des Ersten Weltkriegs, Múnich, C. H. Beck.

Steffen, Hans (ed.) (1965), Der Deutsche Expressionismus: Formen und Gestalten, Gotinga, Vandenhoeck \& Ruprecht.

Talens, Jenaro y Ernst-Edmund Keil (eds.) (1981), Poesía Expresionista Alemana, Madrid, Hiperión.

Washburn, Katharine, John S. Major y Clifton Fadiman (eds.) (1998), World Poetry: An Anthology of Verse from Antiquity to Our Time, Nueva York, W.W. Norton.

Weissenberger, Klaus (2005), «Performing the Poem: Rituals of Activism in Expressionist Poetry», en Neil H. Donahue (ed.), A Companion to the Literature of German Expressionism, Rochester, Camden House, pp. 185-228.

Wilmer, Clive (1982), Devotions, Manchester, Carcanet New Press. 